\title{
SURVEY OF THE USE OF SHORT- ROTATION RYEGRASS
}

\author{
By R. H. SCOTT, Land Utilisation Officer, \\ Department of Agriculture, Wellington
}

Fourteen years have passed since short-rotation ryegrass, or $\mathrm{H}$ I (Hybrid No. I) as it was then called, was first released, and the executive committee of the Grassland Association thought that the time had arrived when a stocktaking could be made of the grass; hence this symposium.

As an introduction to the symposium it was considered that an attempt-should be made-to present $^{-}$some facts ${ }^{-}$about the use or non-use of the grass in the more intensive farming districts of the Dominion. If we had realised early some of the difficulties or traps for inexperienced players in obtaining the information, we may not have allowed our enthusiasm to have got the better of us. However, having committeed ourselves, pride would not let us abandon the project, and in spite of incurring the ire of a number of people, particularly Instructors in Agriculture, we persevered with it.

Also we wished to test the practicability or otherwise of undertaking a Dominion-wide survey of the type necessary to glean information about short-rotation ryegrass. If it proved successful, we considered that the methods evolved might be of use to others in undertaking somewhat similar surveys. You shall be the judge whether or not it has been successful and whether the information which has been collected tells any story.

\section{The Sample}

With approximately 75,000 farm holdings in New Zealand of over 20 acres in area, it was feasible to obtain information from only a very small percentage of this number, and the first task was to work out a method of sampling to select the farms from which information could be obtained.

1. Firstly it was decided to confine the investigations to the more intensive farming districts; that is, those districts where dairying, sheep farming for the production of wool and fat lambs, or farming for the production of cereal or pasture seed crops or 
some combination of these were the feature. All hill areas were excluded where sheep farming for the production of wool, store sheep, and some fat lambs was the system.

2. We still had too large an area to cover in detail and we were now guided by the type of base map available which showed the location of farms and from which the sample of farms could be drawn. We selected the 1 mile to 1 inch topographic maps on which the location of farm homesteads was shown. One of these maps which covers an area of approximately 285,000 acres was selected for most of the districts served by an extension officer of the Department of Agriculture. The map selected was the one which indicated the most intensive land use pattern; that is, the one which had the most intensive roading system and the greatest number of buildings per unit of area.

3. While we would have liked to select 50 or more farms on each map, we had to realise that it was asking rather much of extension officers to obtain information from this number of farmers in a comparatively short period, and finally 10 farms per map were selected on a random basis. It was considered that extension officers would be able to obtain the information from this number of farms in the normal course of their duties. This gave a total sample of 449 farms on 45 maps, these maps covering an area of approximately 3 million acres of intensively farmed land as we had defined it.

Naturally some of the properties selected proved unsatisfactory, but fortunately they were only few. Some were racing stables, some market gardens, poultry units, etc., and where this occurred, a further farm was selected at random and this was substituted for the unsatisfactory unit. I think we can claim that the sample was truly a random one. We certainly found some of our selected farmers to be very versatile. For instance, one extension officer had this comment to make about a selected farm. He said "This farmer's main source of income is derived from night shift work driving a cart for the local Borough Council. His farming appears to be of secondary consideration."

To obtain satisfactory statistical results from a sample of only 10 farms in each extension officer's district was not possible, and we were then faced with the task of combining areas. This was done mainly on the basis of climate, districts having a climate somewhat similar being combined.

The combined districts and the subsidiary districts forming these are as follows: 
Combined Districts

\begin{tabular}{ll}
\hline North Auckland .. & $\begin{array}{c}\text { Kaitaia, Kaikohc, Whangarei, Ruawai, } \\
\text { Maungaturoto, Helensville }\end{array}$ \\
Waikato & $\begin{array}{c}\text { Pukekohe, Hamilton-Cambridge, Te } \\
\text { Awamutu Otorohanga, Ngakuru }\end{array}$ \\
Valley (Rotorua), Matamata & $\begin{array}{c}\text { Paeroa-Netherton, Tauranga, Edge- } \\
\text { cumbe, Lepperton-Waitara (Tara- } \\
\text { naki) }\end{array}$
\end{tabular}

Poverty Bay-Hawke's Bay Gisborne Flats, Heretaunga Plains

Hawera Hawera

Wellington Stratford, Marton, Palmerston North, Dannevirke, Horowhenua, Wellington

Wairarapa, Nelson-Marlborough

Plāins $---$

Greytown - Martinborough, Wairau Plain, Waimea Plain (Nelson)

Sefton - Balcairn (North Canterbury), Lincoln - Ellesmere, Ashburton, Geraldine - Orari, Levels Plain (Timaru)

Downs

Timaru, Waimate, Oamaru, Palmerston

Dunedin

Taieri Plain, Milton

Southland

Kelso, Woodlands, Winton, Drummond-Otautau

Development in Use

The survey indicated that the first district to use short-rotation ryegrass to any significant extent was Canterbury, with the Waikato and Bay of Plenty next. Within 4 years of its release, its use had become widespread, and from 1947 to 1955 considerable numbers of farmers throughout the intensive farming districts began to use the grass for the first time. However, during 1956 and 1957 the number of new farmers to use the grass declined considerably due mainly to saturation point having been reached in some districts; that is, most farmers in these districts were using the grass. This was evident, particularly in the Dunedin and Southland districts.

One would expect that some farmers who began to use shortrotation ryegrass would discontinue to use it, and while our conclusions on this point have to be accepted with some reserva- 


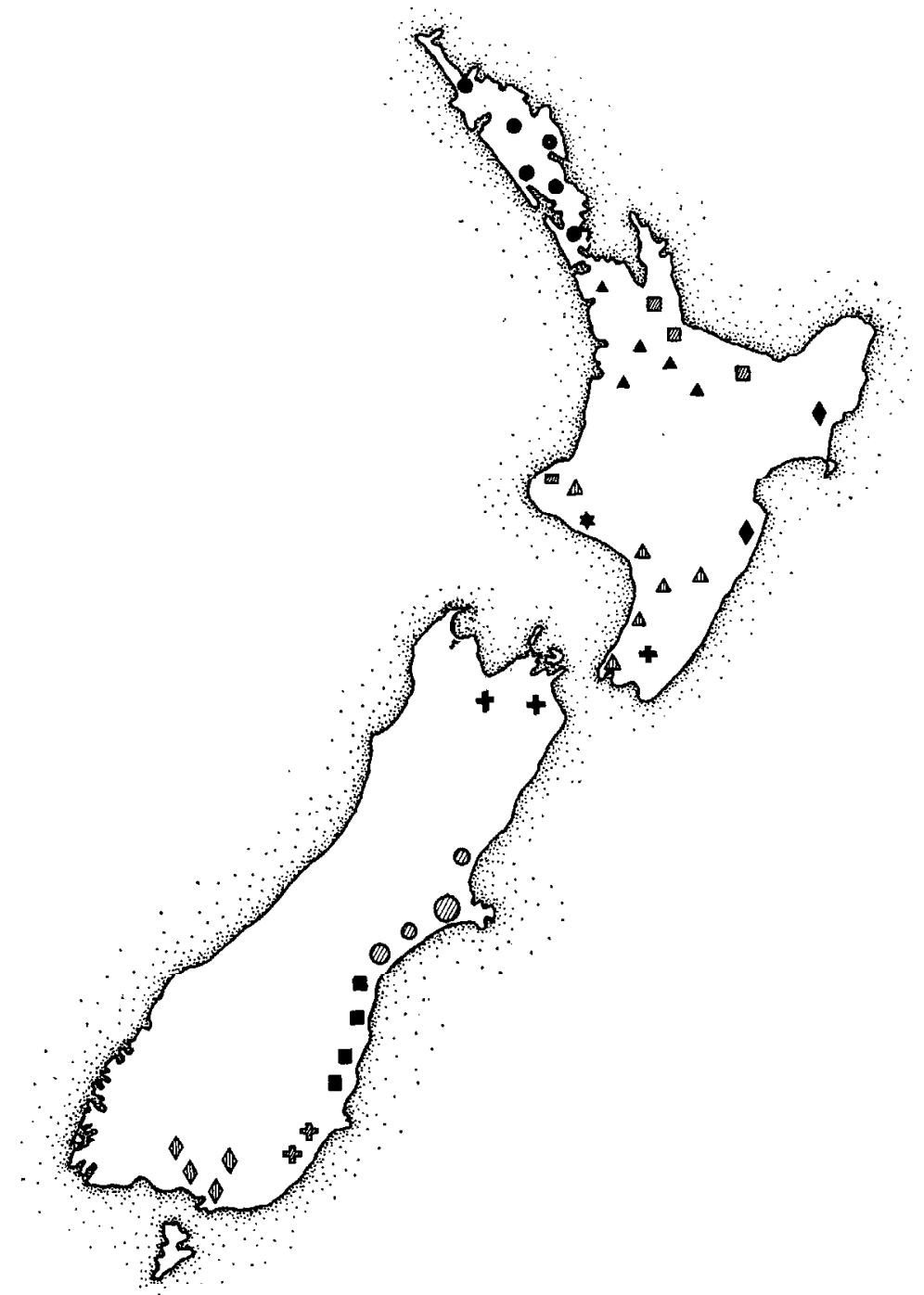

Symbols indicate approximate location of districts in which the survey farms were located. Farms in districts with similar symbols were amalgamated to form a combined district.

tions, it appears that the greatest percentage of casualties was in North Auckland and the Downs region of South Canterbury and North Otago. 


\section{Extent of Use}

Possibly the most interesting result from the survey was that relating to the extent to which the grass is used in the respective intensive farming districts. Table 1 sets this out, the districts being arranged according to the extent to which the grass is used.

Table 1.-percentage of Farmers Using Short-R otation Ryegrass.

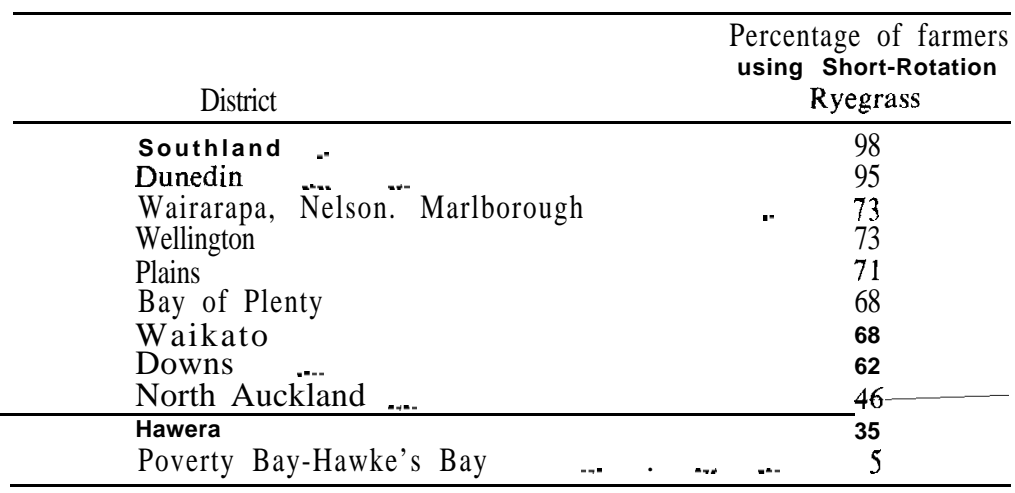

I should point out that although a definite percentage figure has been given, this is not quite correct. The statistician who tried to keep me on the statistical rails tells me that for Southland one can be reasonably confident that between 86 and 99 per cent. of the farmers use the grass, in the Dunedin district 75 to 99 per cent., while in the Poverty Bay-Hawke's Bay area the percentage of farmers will be up to 25 per cent.

The general pattern is one where the further south one goes the greater is the percentage of farmers who use the grass. However, the pattern is partly spoiled by the fact that the percentage of farmers on the South Canterbury and North Otago Downs is not as great as some thought it might be. The low figure for North Auckland is consistent with the criticism that the grass will not persist because of drought and temperature conditions. Also the very low figure for Poverty Bay-Hawke's Ray is what would be expected with a farming system where the production of perennial ryegrass seed is a feature. The low figure for Hawera (Waimate Plain) appears out of place, but here 45 per cent. of the farmers covered in the survey stated they had not resown any pasture during the past 10 years.

\section{P roportion of $P$ asture Sowings in Short-rotation Ryegrass}

The results showed that in those districts where pasture seed production was not a feature, farmers using short-rotation ryegrass in pasture mixtures did not sow down any great area of 
new pasture without including this grass. In the North Auckland, Waikato, Bay of Plenty, and Wellington regions over 80 per cent. of the area of pasture sowings made by farmers in the survey over the past 7 years included short-rotation ryegrass as a constituent. In the Dunedin and Southland regions the percentage was over 70, in the Plains 64 per cent., the Downs 51 per cent., and the low figure of 23 per cent. in the Wairarapa-Nelson-Marlborough region.

The Plains and Downs region had appreciable sowings of shortrotation ryegrass on its own, these being mainly sowings where the grass was used as a greenfeed crop or was sown for seed.

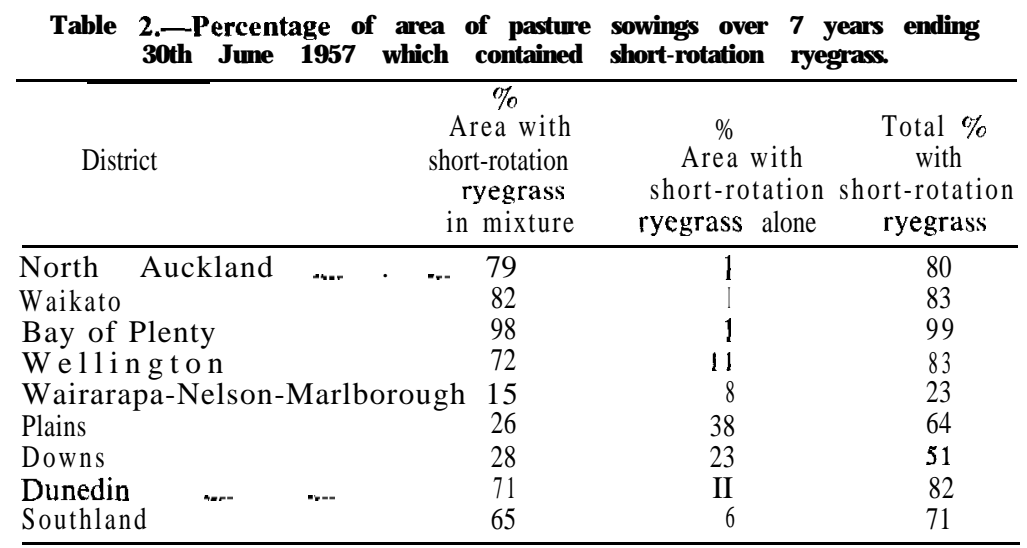

\section{$M$ ethod of Sowing}

Information on the method of sowing showed that except for North Auckland the majority of farmers in other districts sowed on ploughed or cultivated land. In North Auckland about 40 per cent. of the farmers adopted this practice, about one third broadcast on existing pastures, and about one quarter sowed out on surface-worked pasture. In the Waikato and Bay of Plenty some sowings were done by sod seeder, but there was no evidence that this was a significant practice in other districts.

\section{Persistency of Grass}

Opinions were obtained from farmers on how long shortrotation ryegrass persisted in their pastures. While these were opinions, nevertheless they were based on the farmer's own experience with the grass over several years. To obtain a picture of district differences an arbitrary division was made of the life of short-rotation ryegrass in pastures, this division being on the following basis: 
Where short-rotation ryegrass lasted less than 2 years it was classified as "Temporary". Where it lasted over 2 years and up to 4 years the classification was "Short-Rotation", and where it lasted over 4 years it was classified as "Permanent".

The table sets out the district difference. To make peace with our statistical friends, it must be pointed out that the figures cannot be taken as accurate in themselves, but it is considered that they throw into relief the broad district differences.

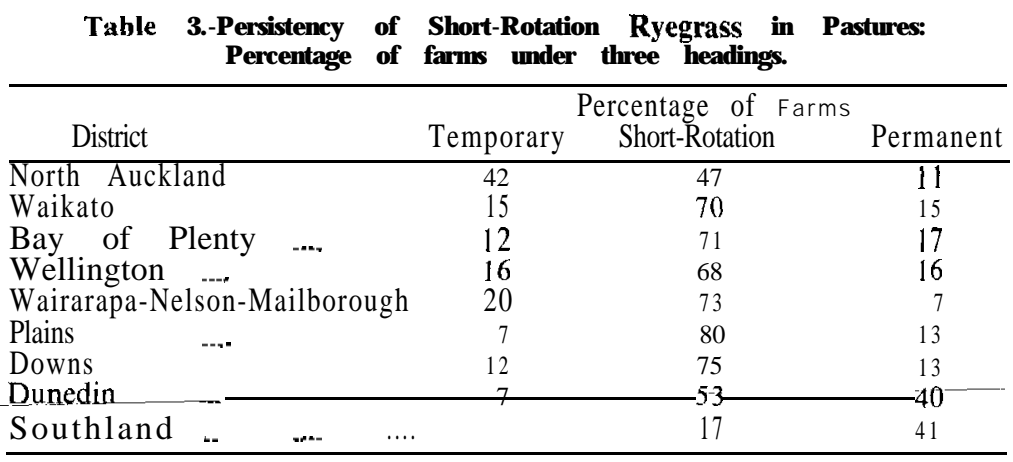

In North Auckland on approximately 42 per cent. of the farms short-rotation ryegrass lasted less than 2 years and on only I I per cent. of the farms was it considered permanent. In the Dunedin and Southland districts the reverse was the case; here, on about 40 per cent. of the farms short-rotation ryegrass was classified as permanent.

As a side issue to this question of persistency we did find that very few of the short-rotation ryegrass users in the survey in the North Island used D.D.T. to control grass-grub, the highest being about 9 per cent. in the Wellington region. However, in the South Island as many as 50 per cent. used D.D.T. in the Plains region and slightly over 30 per cent. in the Dunedin and Southland regions.

\section{Attitudes}

An endeavour was made to obtain an indication of the attitude of farmers towards short-rotation ryegrass, but in this connection I must explain that no one in New Zealand who is engaged in so-called farm management and farm economic investigation work has had any experience in obtaining from farmers their attitudes toward the adoption or non-adoption of particular farm practices. This line of investigation will have to be exploited more fully in future as an aid to extension work. My remarks 
concerning farmers' attitudes toward the grass must therefore be accepted after due allowance for our inexperience has been made.

The most interesting are the attitudes of the non-users. Of all non-users 15 per cent. had sown no new pasture for 10 years, I 1 per cent. were producers of perennial ryegrass seed and did not want these stands contaminated, 6 per cent. considered the grass too short lived, 5 per cent. that it would not stand up to dry conditions, and 6 per cent. had never heard of it, these last including those who considered new-fangled ideas created troubles.

The attitude of the users does not present a very clear-cut position. Forty-nine per cent. of the users supported the grass on the grounds of its good winter and early spring growth, and those in Canterbury, Otago, and Southland also gave it support because of its good late autumn growth. However, among the users, 16 per cent. were not very enthusiastic about the grass, the main criticism being that it would not persist and would not stand dry conditions. This criticism was particularly pronounced in the North Auckland and the Bay of Plenty district.

In the paper I have done nothing more than present the main facts disclosed by the survey. No attempt was made to diagnose the differences between districts. Some of these are, of course, due to climatic and management differences and to the different systems of farming practised. There are many other reasons not so apparent, and no doubt the other papers and discussions resulting from this symposium will throw more light on some of these.

\section{DISCUSSION}

Q. Forty-three per cent. of the non users were quoted in the table and accounted for, but what happened to the other fifty-seven per cent.?

A. The instructors did not comment on those.

Q. Could further details be given of how the data were collected?

A. Each farmer was personally interviewed by the instructor to obtain the answers to the questionnaire.

Q. Were any differences disclosed between pasture mixtures and management practices in the North and South Islands?

A. These data have not been examined as yet. 